\title{
Anti-IL-13 Humanized Monoclonal Antibody TNX-650
}

National Cancer Institute

\section{Source}

National Cancer Institute. Anti-IL-13 Humanized Monoclonal Antibody TNX-650. NCI

Thesaurus. Code C66988.

A humanized monoclonal antibody directed against interleukin-13 (IL-13) with potential antineoplastic activity. Anti-IL-13 humanized monoclonal antibody TNX-650 binds to and blocks the activity of IL-13, which may result in the inhibition of Hodgkin lymphoma cell proliferation. IL-13 cytokine, an important mediator in allergic inflammation, may be an autocrine growth factor for Hodg kin lymphoma cells. 